\title{
PESANTREN TRADISIONAL; \\ AKAR PENYEBARAN ISLAM DAN BAHASA ARAB \\ DI INDONESIA
}

\author{
Moch.Sony Fauzi
}

Dosen Jurusan Bahasa dan Sastra Arab,

Fakultas Humaniora dan Budaya, Universitas Islam Negeri (UIN) Malang.

Jalan Gajayana No. 50 Telepon (0341) 570872, Faksimile (0341) 570872 Malang 65144.

\begin{abstract}
Traditional "pesantren" is the oldest education institution in Indonesia, in which student or santri studies many important materials in Islamic studies such as: Tauhid, Figh, and Tasawwuf. Arabic language as the language of the two main references in Islam, Quran and Hadith, and other classical reference in Islam is also the main object of study in Pesantren because of its importance as a means for understanding the references. The Arabic language is studied deeply especially in the aspect of grammar (qawaid). For this reason, pesantren is not only the center of Islamic studies but also the root of Arabic language in Indonesia.
\end{abstract}

Keywords:

Traditional Pesantren, Arabic Language, Text Book

\section{Pendahuluan}

Membahas tentang sejarah masuknya Islam di Indonesia tidak bisa terlepas dari sebuah lembaga pendidikan tradisional yang bernama pesantren. Sebagai lembaga pendidikan yang tumbuh bersama nafas dinamika masyarakat Islam disekitarnya, pesantren mampu menempatkan dirinya sebagai salah satu agen perubahan masyarakat 
dengan mengusung idealitas teologis yang menjadi dasar pergerakannya.

Abdurrahmad Wahid, menyatakan bahwa pesantren nyaris menjadi kekuatan subkultur masyarakat Islam di Indonesia, dengan melalui proses pembentukan tata nilai tersendiri di dalam pesantren, lengkap dengan simbol-simbolnya, adanya daya tarik ke luar, sehingga memungkinkan masyarakat sekitar menganggap pesantren sebagai alternatif ideal bagi sikap hidup yang ideal dalam masyarakat itu sendiri, dan berkembangnya suatu proses pengaruh mempengaruhi dengan masyarakat di luarnya, yang akan berkulminasi pada pembentukan nilai-nilai baru yang secara universal diterima oleh kedua belah pihak (Wahid, 1974:40). Sehingga praktis sejarah penyebaran nilai Islam dalam masyarakat Indonesia baik secara langsung maupun tidak langsung akan bersentuhan dengan tradisi pesantren.

Selaras dengan penyebaran Islam ini, ada sebuah implikasi penting yang layak untuk menjadi bahan kajian, yaitu penyebaran bahasa Arab, sebagai bahasa kitab suci Al-Quran, bahasa ibadah, dan khasanah keilmuan Islam yang menurut Dr. Hidayatulloh Zarkasiy, bahasa Arab dan penyebaran Islam di Indonesia merupakan dua bagian yang tidak bisa dipisahkan, karena bahasa ini selalu melekat dalam aktivitas ibadah yang dilakukan seorang muslim, terutama dalam sholat, inilah untuk pertama kali umat Islam memiliki keinginan mempelajari bahasa Arab, dimulai dari pelafalan huruf-huruf Hijaiyah hingga pada tahap pemahaman makna kata dan struktur kalimat (Zarkashiy, 1991:73).

Eksistensi pesantren tradisional juga menempati posisi penting dalam penyebaran bahasa Arab di Indonesia melalui halaqoh-halaqoh keilmuan Islam yang dikembangkan di dalamnya. Pesantren juga membekali para santri dengan disiplin ilmu kebahasaan Arab sebagai alat untuk memahami Al-Quran dan literatur keagamaan Islam yang berbahasa Arab, sehingga terjadi sebuah perjumpaan antara pesantren tradisional, penyebaran Islam, dan penyebaran bahasa Arab dalam pembentukan peradaban Islam Indonesia yang khas. 


\section{Pengertian Pesantren Tradisional}

Kata pesantren sebenarnya berakar dari kata santri yang menurut Prof. A.H. Johns, kata tersebut adalah bahasa Tamil, yang berarti guru mengaji. Sedangkan CC.Berg berpendapat bahwa istilah tesebut berasal dari istilah shastri yang dalam bahasa India berarti orang yang tahu buku-buku suci agama Hindu, atau seorang sarjana ahli kitab suci agama Hindu. Kata Shastri berasal dari shastra yang berarti buku-buku suci, buku-buku agama atau buku-buku agama atau buku-buku pengetahuan (Dhofier, 1994:18). Tetapi, walaupun istilah santri berdekatan dengan bahasa agama Hindu, namun di Indonesia kata yang kemudian berubah menjadi kata pesantren ini lazim digunakan dalam khasanah kelembagaan pendidikan Islam.

Secara terminologis, pesantren adalah lembaga pendidikan dan pengajaran agama Islam.Umumnya, proses pendidikan pesantren berlangsung secara non klasikal, dimana seorang kyai mengajarkan ilmu agama Isalam kepada santri-santri berdasarkan kitab-kitab yang ditulis dalam bahasa Arab oleh ulama abad pertengahan, dan para santri biasanya tinggal di pondok (asrama) dalam pesantren tersebut. (Prasodjo, 1982:6). Kyai di sini adalah seorang guru yang menjadi tokoh sentral dalam pesantren, yang dari kemampuan pribadinya, pertumbuhan suatu pesantren tergantung padanya (Dhofier, 1994:55). Santri adalah murid-murid yang sengaja menuntut ilmu di pesantren, baik ia bermukim di sana ataupun tidak.

Adapun istilah tradisional, ia berasal dari kata tradisi yang dalam khasanah bahasa Indonesia berarti segala sesuatu seperti adat, kebiasaan, ajaran dan sebagainya, yang turun temurun dari nenek moyang (Poerwadarminta, 1982:1088). Ada pula yang menuturkan bahwa tradisi berasal dari kata traditum, yaitu segala sesuatu yang ditranmisikan, diwariskan oleh masa lalu ke masa sekarang. Dan ketika kata ini berubah menjadi kata tradisional yang berarti menurut adat, turun-temurun, maka sebagaimana diketahui kata tradisional dipergunakan untuk mensifati sesuatu, misalnya kata tari atau pakaian tradisional, yaitu tari atau pakaian menurut adat atau yang diwarisi 
turun temurun. Dalam aspek-aspek yang lain kita mengenal istilahistilah upacara tradisional, pengobatan tradisional dan sebagainya (Bawani, 1993:24).

Merujuk kepada pengertian-pengertian di atas, pesantren tradisional bisa didefinisikan sebagai lembaga pendidikan Islam yang dikelola berdasarkan pola-pola lama yang sengaja dilestarikan, pengajarannya menggunakan kurikulum yang diadopsi dari warisan masa sebelumnya dan dilakukan secara turun temurun.

\section{Sejarah Pondok Pesantren Tradisional}

Pendidikan Islam, secara kelembagaan, dalam catatan sejarah tampak dalam bentuk yang bervariasi. Di samping lembaga yang bersifat umum seperti masjid, terdapat lembaga-lembaga lain yang mencerminkan kekhasan orientasinya. Secara umum, pada abad keempat Hijrah dikenal beberapa sistem pendidikan (Madaris AlTarbiyah) Islam.

Hasan Abdul Al-'Al, menyebutkan lima sistem dengan klasifikasi sebagai berikut; Sistem Pendidikan Mu'tazilah, Sistem Pendidikan Ikhwan Al-Shafa, Sistem Pendidkan Bercorak Filsafat, Sistem Pendidikan Bercorak Tasawwuf, dan Sistem Pendidikan Bercorak Fiqh. Adapun Hassan Muhammad Hassan dan Nadiyah Muhammad Jamaluddin juga menyebutkan lima sistem, masingmasing; Sistem Pendidikan Bercorak Teologi, Sistem Pendidikan Bercorak Syiah, Sistem Pendidkan bercorak filsafat, Sistem Pendidikan Bercorak Tasawwuf, dan Sistem Pendidikan bercorak Fiqh dan AlHadis.

Institusi yang dipakai masing-masing dapat digambarkan sebagai berikut :

\begin{tabular}{|c|l|l|}
\hline & \multicolumn{1}{|c|}{ Golongan } & \multicolumn{1}{c|}{ Istilah yang digunakan } \\
\hline 1 & Failusuf & $\begin{array}{l}\text { Dar Al-Hikmah, Al-Muntadiyat, } \\
\text { Hawanit dan Warraqqiin }\end{array}$ \\
\hline
\end{tabular}




\begin{tabular}{|c|l|l|}
\hline 2 & Mutashawwif & $\begin{array}{l}\text { Al-Zawaaya, Al-Ribath, Al-Masaajid, } \\
\text { dan Halaqat Al-Dzikr }\end{array}$ \\
\hline 3 & Syii'iyyiin & $\begin{array}{l}\text { Dar Al-Hikmah, Masaajid, dan } \\
\text { Pertemuan Rahasia }\end{array}$ \\
\hline 4 & Mutakallimin & $\begin{array}{l}\text { Al-Masajid, Al-Maktabat, Hawanit, Al- } \\
\text { warraqin, dan Al-Muntadiyat }\end{array}$ \\
\hline 5 & $\begin{array}{l}\text { Fuqaha dan } \\
\text { Al-Muhaddtsiin }\end{array}$ & Al-Katatib, Al-Madaris, dan Al-Masajid \\
\hline
\end{tabular}

Masing-masing sistem di atas memiliki institusi yang khusus walaupun umumnya memanfaatkan masjid. Menurut Hassan dan Nadiyah institusi-institusi itu terkait dengan pendidikan-pendidikan yang dilakukan dan aliran-aliran pemikiran Islam yang berkembang di dalamnya (Maksum, 1999:52).

Cyril Glasse, dalam ensiklopedi Islamnya menulis bahwa dar Alhikmah adalah sebuah akademi yang didirikan khalifah Fathimiyah, AlHakim (w.411/1021), di Kairo sebagai perluasan istananya, tempat ini juga tempat berkumpulnya kalangan cendekiawan dan sekaligus sebagai pusat penyiapan para da'i (propagandis) untuk menyebarkan ajaran Syiah Ismailiyah (Glasse, 1999:71).

Adapun Zawiyah/Zawaya, di Afrika Utara istilah ini berarti sebuah tempat ibadah/sebuah masjid kecil, sebuah tempat pengasingan untuk kegiatan keagamaan, atau secara khusus tempat pertemuan para sufi untuk melaksanakan doa dan dzikir (Glasse, 1999:447). Sedangkan Ribath bersesuaian dengan zawiyah, tempat pertemuan para sufi. (Glasse, 1999:343).

Tempat-tempat di atas kalau dicermati, awalnya bukan sebagai tempat yang secara khusus dibangun untuk sarana pendidikan, namun lebih dari sebuah implikasi dari fungsi masjid sebagai sentrum kegiatan masyarakat muslim, karena implikasi itu terus bertambah sehingga masjid menjadi multifungsi. Seiring dengan perkembangan itu peribadatan di masjid menjadi terganggu oleh suara bising dan 
kegaduhan yang ditimbulkan oleh proses pengajaran, sehingga dibangunlah kuttab-kuttab sebagai tempat penyelenggaraan pendidikan dan model inilah yang diadopsi oleh penyebar agama Islam di Indonesia menjadi pondok pesantren. Sebagaimana dikatakan George Makdisi, bahwa pesantren di Indonesia menyerupai madrasahmadrasah di Baghdad pada abad 11-12 M, terdiri dari masjid, asrama/pondok, dan kelas belajar (Maksum, 1999:80).

Dengan akar sejarah seperti itu, sebagian sarjana di Indonesia berasumsi bahwa tradisi pendidikan Islam di Indonesia tidak sepenuhnya khas Indonesia, kecuali hanya menambahkan muatan dan corak keislaman terhadap terhadap tradisi pendidikan yang sudah ada. Bahkan masuknya Islam tidak mengubah format penyelenggaraan yang sebelumya sudah ada dan mentradisi, namun yang paling pokok adalah materi yang dipelajari, bahasa, dan latar belakang pelajar-pelajar (Sumanjuntak, 1973:24). Namun satu hal yang sepertinya sangat tersepekati adalah bahwa sejarah berdirinya pesantren sangat erat hubungannya dengan sejarah masuknya Islam di Indonesia (Bimbaga, 2003:7).

\section{Pengajaran Bahasa Arab di Pesantren Tradisional}

Pondok pesantren adalah sebuah sistem yang unik. Tidak hanya unik dalam pendekatan pengajarannya, tapi juga unik dalam pandangan hidup dan tata nilai yang dianut, cara hidup yang ditempuh, struktur kewenangan, serta semua aspek-aspek kependidikan dan kemasyarakatan lainnya. Dari perbagai corak dan model pesantren yang ada yang di Indonesia, secara umum paling tidak ada 5 (lima) unsur pembentuk pesantren, yaitu: 1) kyai, 2) santri, 3) pengajian, 4) asrama/pondok, dan 5) masjid.

Kelima unsur pembentuk pesantren itu biasanya tersentral kepada figur kyai yang memimpin/mendirikan pesantren itu, segala macam aktivitas yang ada dalam pesantren harus atas sepengetahuan dan persetujuan sang kyai, termasuk pembelajaran yang ada di dalamnya semua terpusat pada kyai, kalaupun ada sistem klasikal yang 
berjenjang, yang setiap kelas diajar oleh ustadz-ustadz muda, maka semua pengajar di kelas itu adalah orang-orang yang direkomendasiakan sang kyai. Di sini, kyai adalah pusat dari gerakan kelompok yang terwadahi dalam pesantren tersebut. Dalam subbab ini penulis akan menguraikan beberapa hal yang terkait dengan pembelajaran agama Islam dan bahasa Arab di pesantren antara lain: kurikulum/manhaj, masa pembelajaran dan syahadah, serta metode pembelajaran.

\section{Kurikulum/Manhaj}

Sebenarnya pesantren tradisional tidak memiliki kurikulum formal seperti yang dipakai dalam lembaga pendidikan modern, karena kurikulum yang ada di dalamnya tidak memiliki silabus, tapi berupa funun kitab-kitab yang diajarkan pada santri. Kitab-kitab dari berbagai disiplin ilmu yang telah ditentukan oleh sang kyai harus dipelajari sampai tuntas, sebelum naik ke kitab lain yang tingkat kesukarannya lebih tinggi.

Tamatnya program pembelajaran tidak diukur oleh satuan waktu, juga tidak diukur pada penguasaan tehadap topik-topik tertentu, namun diukur dari ketuntasan dan kepahaman santri pada kitab yang dipelajarinya. Kompetensi standar bagi tamatan sebuah pesantren adalah kemampuan menguasai, memahami, menghayati, mengamalkan, dan mengajarkan isi kitab tertentu yang telah ditetapkan. Kompetensi standar ini tercermin pada penguasaan kitab-kitab secara graduatif, berurutan dari yang ringan sampai yang berat, dari yang mudah sampai yang sukar, dari kitab yang tipis sampai yang tebal dan berjilid-jilid. Kitab-kitab itu disebut kitab kuning, disebut demikian karena dicetak di atas kertas berwarna kuning, juga disebut kitab "gundul" (botak) karena huruf-hurufnya tidak ber-syakal (ber-harakat) (Bimbaga, 2003:32).

Di bawah ini contoh jenis fan dan kitab yang diajarkan berdasarkan tingkatnya (Zarkashy, 199184): 


\begin{tabular}{|c|c|c|c|}
\hline & Pendidikan & (Fan) & \\
\hline \multirow{6}{*}{ A } & \multirow{6}{*}{$\begin{array}{l}\text { Tingkat } \\
\text { Dasar }\end{array}$} & 1. Al-Qur'an & - Mushaf \\
\hline & & 2. Tauhid & $\begin{array}{l}\text { - Al Jawahir Al-Kalamiyyah } \\
\text { - Ummu Al-Barohim }\end{array}$ \\
\hline & & 3. Fiqih & $\begin{array}{l}\text { - Safinah Al-Sholah } \\
\text { - Safinah Al-Najah } \\
\text { - Sullam Al-Taufiq } \\
\text { - Sullam Al-Munajat } \\
\end{array}$ \\
\hline & & 4. Akhlak & $\begin{array}{l}\text { - Al-Washaya Al-Abna } \\
\text { - Al Akhlaq li Al-Banin/banat }\end{array}$ \\
\hline & & 5. Nahwu & $\begin{array}{l}\text { - Al-Nahw Al-Wadlih } \\
\text { - Al-Ajrumiyyah }\end{array}$ \\
\hline & & 6. Sharaf & $\begin{array}{l}\text { - Al-Amtsilah Al-Tashrifiyyah } \\
\text { - Matn Al-Bina wa Al-Asas }\end{array}$ \\
\hline \multirow{7}{*}{ B } & \multirow{7}{*}{$\begin{array}{l}\text { Tingkat } \\
\text { Menengah } \\
\text { Pertama }\end{array}$} & 1. Tajwid & $\begin{array}{ll}\text { - } & \text { Tuhfah Al-Athfal } \\
\text { - } & \text { Hidayah Al-Mustafid } \\
\text { - } & \text { Mursyid Al-wildan } \\
\text { - } & \text { Syifa' Al-Rahman } \\
\end{array}$ \\
\hline & & 2. Tauhid & $\begin{array}{l}\text { - Aqidah Al-awwan } \\
\text { - Al-Din Al-Islami }\end{array}$ \\
\hline & & 3. Fiqih & $\begin{array}{l}\text { - Fath Al-Qorib ( Taqrib ) } \\
\text { - Minhaj Al-Qawim Safinah Al-Sholah }\end{array}$ \\
\hline & & 4. Akhlak & - Ta'lim Al-Muta'allim \\
\hline & & 5. Nahwu & $\begin{array}{l}\text { - } \text { Mutammimah } \\
\text { - Nadzom 'Imrithi } \\
\text { - } \text { Al-Makudi } \\
\text { - } \text { Al-'Asymawi }\end{array}$ \\
\hline & & 6. Sharaf & $\begin{array}{l}\text { - Nizaham Al-maksud } \\
\text { - Al-Kailani }\end{array}$ \\
\hline & & 7. Tarikh & - Nur Al-Yaqin \\
\hline C & $\begin{array}{l}\text { Tingkat } \\
\text { Menengah } \\
\text { Atas }\end{array}$ & 1. Tafsir & $\begin{array}{l}\text { - Tafsir Al-Qur'an Al-Jalalain } \\
\text { - Al-Tibyan fi 'Ulumu Al-Qur'an } \\
\text { - Mahabits fi 'Ulumul Al-Qur'an } \\
\text { - Manahil Al-Irfan }\end{array}$ \\
\hline
\end{tabular}




\begin{tabular}{|c|c|c|c|}
\hline & & 2. Hadis & 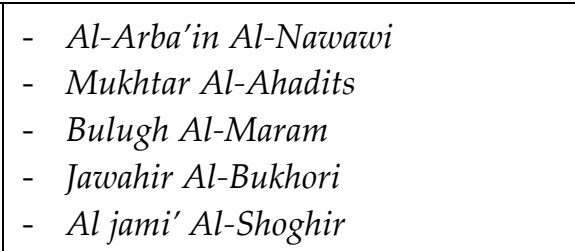 \\
\hline & & $\begin{array}{l}\text { 3. Musthalah } \\
\text { Hadis }\end{array}$ & $\begin{array}{l}\text { - Minhah Al-Mugits } \\
\text { - Al-Baiquniyyah }\end{array}$ \\
\hline & & 4. Tauhid & $\begin{array}{ll}\text { - } & \text { Tuhfah Al-Murid } \\
\text { - } & \text { Al-Husun Al-Hamidiyah } \\
\text { - } & \text { Al-Aqidah Al-Islamiyah } \\
\text { - } & \text { Kifayah Al-Awwam } \\
\end{array}$ \\
\hline & & 5. Fiqh & - Kifayah Al-Akhyar \\
\hline & & 6. Ushul Fiqh & $\begin{array}{l}\text { - Al-Waraqat } \\
\text { - Al-Sullam } \\
\text { - Al-Bayan } \\
\text { - Al-Luma' }\end{array}$ \\
\hline & & $\begin{array}{l}\text { 7. Nahwu- } \\
\text { Sharaf }\end{array}$ & 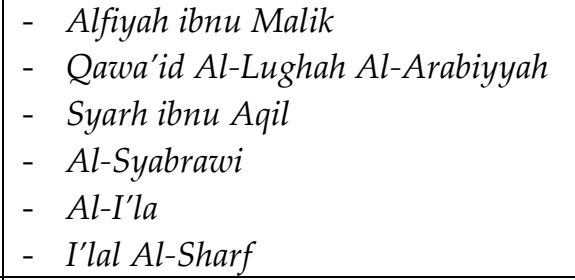 \\
\hline & & 8. Akhlak & $\begin{array}{l}\text { - Minhal Al-Abidin } \\
\text { - Irsyad Al-'ibad } \\
\end{array}$ \\
\hline & & 9. Tarikh & - Ismam Al-Wafaq \\
\hline & & 10.Balaghah & - Al-Jauhar Al-Maknun \\
\hline & & 1. Tauhid & - Fath Al-Majid \\
\hline$D$ & Tingkat & 2. Tafsir & $\begin{array}{l}\text { - Tafsir Qur'an Al-Adzim Ibnu Katsi } \\
\text { - Fi Zhilal Al-Qur'an }\end{array}$ \\
\hline & & 3. Ilmu Tafsir & $\begin{array}{l}\text { - Al-Itqan fi ulum Al-Qur'an } \\
\text { - Itmam Al-Dirayah }\end{array}$ \\
\hline
\end{tabular}




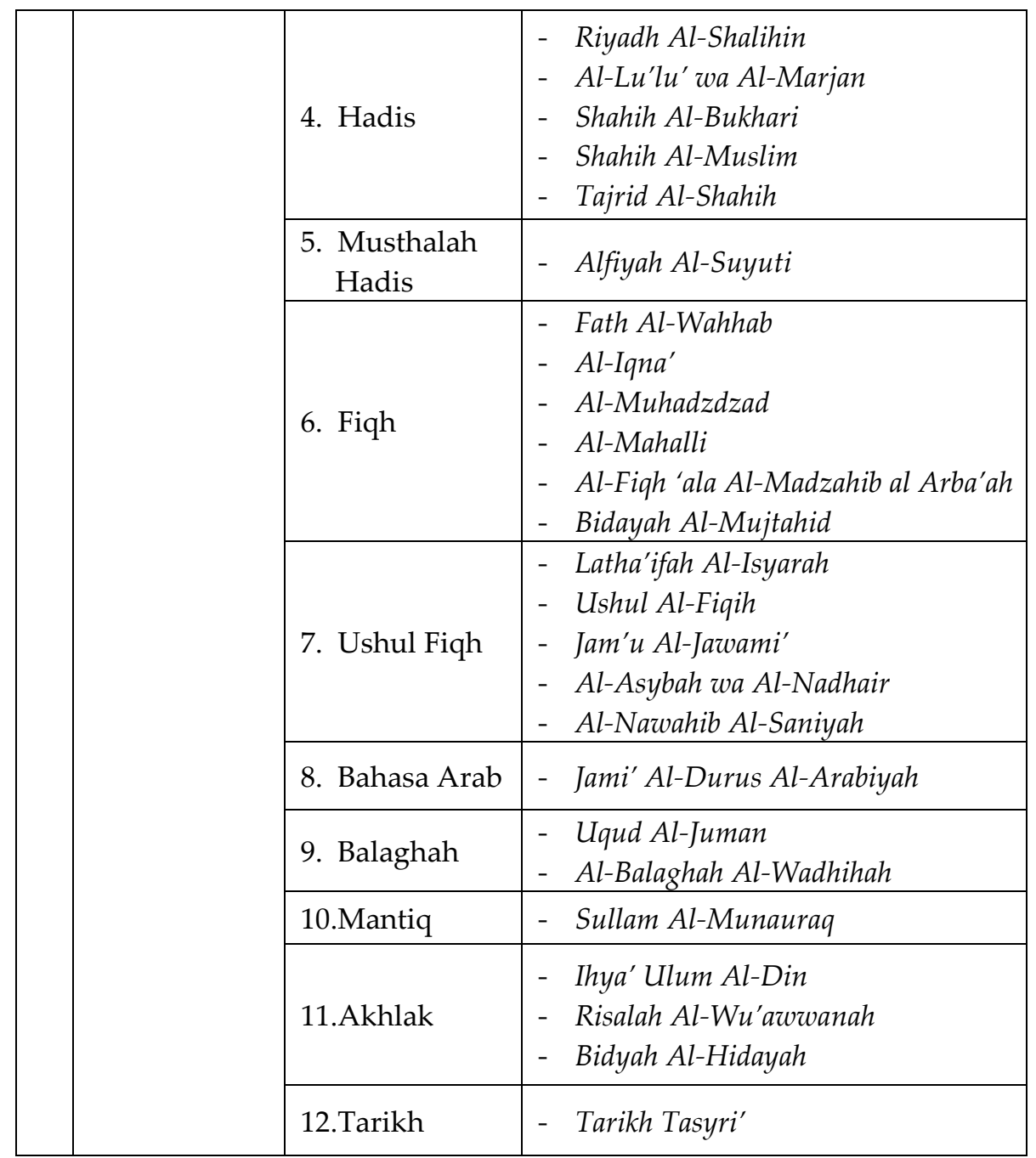

Kitab-kitab itu pada umumnya dipergunakan dalam pengajian standart oleh pondok-pondok pesantren. Selain yang telah dikemukakan diatas, masih banyak kitab-kitab yang dipergunakan untuk pendalaman pengetahuan ajaran islam. Misalnya kitab-kitab berikut (Bimbaga, 2003:36): 


\begin{tabular}{|c|c|c|}
\hline & Bidang Studi & Nama Kitab \\
\hline 1 & $\begin{array}{l}\text { Bidang Tafsir/ } \\
\text { Ilmu Tafsir }\end{array}$ & $\begin{array}{l}\text { 1. } \text { Ma'ani al Qur'an } \\
\text { 2. Al Basith } \\
\text { 3. Al Bahal al muhith } \\
\text { 4. Jami' Al-Ahkam Al-Qur'an } \\
\text { 5. Ahkam Al-Qur'an } \\
\text { 6. Mafatih Al-Ghaib } \\
\text { 7. Lubab Al-Nuqul fi Asbab Nuzul Al-Qur'an } \\
\text { 8. Al-Burhan fi'Ulum Al-Qur'an } \\
\text { 9. I'jazal Qur'an }\end{array}$ \\
\hline 2 & Bidang Hadis & $\begin{array}{ll}\text { 1. } & \text { Al Muwaththa' } \\
\text { 2. Sunan Al-Turmudzi } \\
\text { 3. Sunan Abu Daud } \\
\text { 4. Sunan Al-Nasa'I } \\
\text { 5. Sunan Ibn Majah } \\
\text { 6. Al-Musnad } \\
\text { 7. Al-Targhib wa Al-Tharhiib } \\
\text { 8. Nail Al-Awthar } \\
\text { 9. Subul Al-Salam }\end{array}$ \\
\hline 3 & Bidang Fiqih & $\begin{array}{ll}\text { 1. } & \text { Al-Syarh Al-Kabir } \\
\text { 2. } & \text { Al-Umm } \\
\text { 3. } & \text { Al-Risalah } \\
\text { 4. } & \text { Al-Muhalla } \\
\text { 5. } & \text { Figh Al-Sunnah } \\
\text { 6. Min Taujihah Al-Islam } \\
\text { 7. Al-Fatawa } \\
\text { 8. Al-Mughni li Ibn Qudamah } \\
\text { 9. } \\
\text { Zaad Al-Maad }\end{array}$ \\
\hline
\end{tabular}

Dalam pelaksanaannya, perjenjangan diatas tidaklah mutlak. Dapat saja pondok pesantren memberikan tambahan atau melakukan langkah-langkah inovasi, misalnya mengjarkan kitab-kitab yang populer, tetapi lebih mudah dalam penyajiannya, sehingga lebih efektif para santri menguasai materi. 
Dengan jenis materi seperti di atas, terlihat bahwa pesantren tradisional memegang peranan penting dalam penyebaran Islam dan bahasa Arab di Indonesia, ditambah lagi dengan penerapan metode pengajaran khas yang memungkinkan seorang santri menguasai bahasa Arab melalui pengayaan mufrodat dan penguasaan tata bahasa Arab (Nahwu dan Sharaf).

\section{Metode Pembelajaran}

Metode pembelajaran dapat diartikan sebagai cara-cara yang dipergunakan untuk menyampaikan ajaran sampai ke tujuan. Dalam kaitannya dengan pondok pesantren salafiyah, ajaran adalah apa yang terdapat dalam kitab kuning, kitab rujukan, refrensi yang dipegang oleh pondok pesantren tersebut. Pemahaman terhadap teks-teks ajaran tersebut dapat dicapai melalui metode paembelajaran tertentu yang bisa digunakan oleh pondok pesantren. Selama kurun waktu panjang pondok telah memperkenalkan dan menerapkan beberapa metode pembelajaran.

Metode pembelajaran di pondok pesantren salafiyah ada yang bersifat tradisional, yaitu pembelajaran yang diselenggarakan menurut kebiasaan yang telah lama dilaksanakan pada pesantren atau dapat juga disebut metode pembelajaran asli (original) pondok pesantren. Namun karena perkembangan jaman dimasa-masa selanjutnya sudah mulai ditemukan di beberapa pesantren tradisional metode pembelajaran modern (tajdid). Metode pembelajaran modern merupakan metode pembelajaran hasil pembaharuan kalangan pondok pesantren dengan memaksukkan metode yang berkembang pada masyarakat modern, walaupun tidak selalu diikuti dengan menerapkan sistem modern, yaitu sistem sekolah atau madrasah. Beberapa Pondok pesantren tradisional sebenarnya telah pula menyerap sistem klasikal. Tetapi tidak dengan batas-batas fisik yang tegas sebagaimana sistem klasikal pada persekolahan modern (Bimbaga, 2003:37).

Berikut ini beberapa metode pembelajaran tradisional yang menjadi ciri utama pembelajarn di pondok pesantren tradisional 
Pertama, Metode Sorongan. Sorongan, berasal dari kata sorog (bahasa jawa), yang berarti menyodorkan (Bimbaga, 2003:38), sebab setiap santri menyodorkan kitabnya dihadapan kyai atau pembantunya (badal, asisten kyai). Sistem sorogan ini termasuk belajar secara individual, dimana seorang santri berhadapan dengan seorang guru, dan terjadi interaksi saling mengenal diantara keduanya. Sistem sorogan ini terbukti sangat lebih efektif sebagai taraf pertama bagi seorang murid yang bercita-cita menjadi seorang alim. Sistem ini memungkinkan seorang guru mengawasi, menilai dan menimbang secara maksimal kemampuan seorang santri dalam menguasai materi pembelajaran. Sorogan merupakan kegiatan pembelajaran bagi para santri yang menitik beratkan pada pengembangan kemampuan perorangan (individual), dibawah bimbingan seorang kyai atau ustadz.

Pembelajaran dengan sistem sorogan diselenggarakan pada ruang tertentu. Ada tempat duduk kyai atau ustadz, didepannya ada meja pendek untuk meletakkan kitab bagi santri yang menghadap. Santri-santri lain, baik yang mengaji kitab yang sama ataupun kitab yang berbeda duduk agak jauh sambil mendengarkan apa yang diajarkan oleh kyai atau ustadz sekaligus mempersiapkan diri menunggu giliran dipanggil.

Sistem ini memiliki satu kaidah penerjemahan yang khas dari bahasa Arab setiap jabatan kata dalam kalimat berbahasa Arab memiliki kode tertentu sehingga secara tidak langsung ada proses internalisasi pemahaman tata bahasa Arab. Kalimat demi kalimat diterjemahkan ke bahasa daerah, dibawah setiap kata Arab biasanya ada terjemahan dengan bahasa lokal daerah, dengan menggunakan huruf "Arab Pegon".

Kyai atau ustadz mendengarkan dengan tekun pula apa yang dibacakan santrinya sambil melakukan koreksi-koreksi seperlunya. Setelah tampilan santri dapat diterima, tidak jarang juga kyai memberikan tambahan penjelasan agar apa yang dibaca oleh santri dapat lebih dipahami. Metode pembelajaran ini termasuk metode pembelajaran yang sangat bermakna karena santri merasa berhubungan 
khusus ketika berlangsung pembacaan kitab dihadapan kyai. Mereka tidak saja senantiasa dapat dibimbing dan diarahkan cara membacanya tetapi dapat dievaluasi perkembangan kemampuannya. Berdasarkan penelitian Zamakhsyari Dhofier, sistem ini sangat efektif pada taraf awal pendidikan santri terutama dalam penguasaan bahasa Arab (Dhofier, 1994:29).

Namun sekalipun kelihatannya metode ini hanya cocok untuk pemula tetapi dapat juga dipakai untuk tingkat kelanjutan bahkan tingkat tinggi. Untuk tingkat lanjutan dapat saja yang memulai membaca adalah santri, kyai atau ustadz hanya mendengarkan dan memperhatikan kefasihan, ketepatan ucapan, sekaligus memparhatikan tingkat pemahaman santri terhadap apa yang dibacanya (Bimbaga, 2003:39).

Kedua, Metode Wetonan/Bandongan. Wetonan, istilah wetonan ini berasal dari kata wektu (bahasa Jawa) yang berarti waktu, sebab pengajian tersebut diiberikan pada waktu-waktu tertentu, yaitu sebelum dan sesudah melakukan shalat fardhu. Metode weton ini merupakan metode kuliah, dimana para santri mengikuti pelajaran dengan duduk disekeliling kyai yang menerangkanpelajaran kuliah, santri menyimak kitab masing-masing dan membuat catatan padanya. Istilah wetonan ini di Jawa Barat disebut dengan bandongan (Bimbaga, 2003:40).

Metode bandongan dilakukan oleh kyai atau sekelompok santri untuk mendengarkan dan menyimak apa yang dibacakan oleh kyai dari sebuah kitab. Kyai membaca, menerjemahkan, menerangkan dan seringkali mengulas teks-teks kitab berbahasa Arab tanpa harokat (gundul). Santri dengan memegang kitab yang sama, masing-masing melakukan pendhabithan harakat kata langsung dibawah kata yang dimaksudagar dapat memnbantu memahami teks. Posisi para santri pada pembelajaran dengan metode ini adalah melingkari dan mengelilingi kyai atau ustadz sehingga dapat membentuk halaqah (lingkaran). Dalam penerjemahannya, kyai atau ustadz dapat juga menggunakan berbagai bahasa yang menjadi bahasa utama para 
santrinya, misalnya ke dalam bahasa Jawa, Sunda atau bahasa Indonesia.

Hampir disemua pesantren tradisional menggunakan sistem ini secara maksimal dengan pengajaran yang yang berkesinambungan dari bab ke bab selanjutnya dengan menerjemahkan arti per-kata dan saat tertentu kyai juga menyinggung kaidah-kaidah ilmu nahwu yang terkait dengan kalimat yang sedang beliau terjemahkan, dan santri akan menirukan seperti apa yang dibacakan oleh kyai (Yunus, 1979:56).

Berkaitan dengan kegiatan penilaian, biasanya kyai atau ustadz memiliki catatan-catatan khusus sehingga para santri belajar belajar sungguh-sungguh karena merasa diawasi dan dimonitor perkembangan kemampuannya (Bimbaga, 2003:43).

Ketiga, Metode Musyawarah atau Bahtsul Masa'il. Metode musyawarah atau dalam istilah lain bahtsul masa'il merupakan metode pembelajaran yang mirip dengan metode diskusi atau seminar. Beberapa orang santri dalam jumlah tertentu membentuk halaqah yang dipimpin langsung oleh kyai atau ustadz, atau mungkin santri senior, untuk membahas atau mengkaji suatu persoalanyang telah ditentukan sebelumnya. Dalam pelaksanaanya, para santri dengan bebas mengajukan pertanyaan atau pendapatnya. Dengan demikian metode ini menitik beratkan pada kemampuan perseorangan didalam menganalisis dan memecahkan suatu persoalan dengan argumen logika yang mengacu pada kitab-kitab tertentu. Musyawarah pada bentuk kedua ini bisa digunakan oleh santri tingkat menengah atau tinggi untuk membedah topic materi tertentu.

Untuk melakukan pembelajaran dengan menggunakan metode musyawarah kyai atau ustadz biasanya mempertimbangkan ketentuanketentuan, yaitu: 1) Peserta musyawarah adalah para santri yang berada pada tingkat menengah atau tinggi. 2) Peserta musyawarah tidak memiliki perbedaan kemampuan mencolok. Ini untuk mengurangi kegagalan musyawarah. 3) Topik atau persoalan (materi) yang dimusyawarahkan biasanya ditentukan terlebih dahulu oleh kyai atau ustadz pada pertemuan sebelumnya. 4) Pada beberapa pesantren yang 
memiliki santri yang tingkat tinggi, musyawarah dapat dilakukan secara terjadwal sebagai latihan untuk para santri.

Langkah persiapan terpenting pada metode ini adalah terlebih dahulu memberikan topic-topik materi yang akan dimusyawarahkan. Pilihan topic itu sendiriamat menentukan. Topic yang menarik umumnya mendapat respon yang baik danmemberikan dorongan yang kuat kepada para santri untuk belajar. Penentuan topic secara lebih awak ini dimaksudkan agar para peserta dapat mempersiapkan diri jauh-jauh hari sebelum pelaksanaan. Selain itu juga disampaikan penjelasan tentang cara-cara yang dilakukan berkenaan dengan dipihnya metode musyawarah.

Sebagai permulaan, kyai atau ustadz, atau salah satu santri senior menjelaskan secara singkat permasalahan yang akan dibahas. Pada pesantren yang memiliki ma'had 'aly (takhosus tingkat tinggi) penyaji adalah para santri yang telah disusun secara terjadwal dengan topic tertentu untuk menyampaikan pemikiran-pemikiran atau persoalan-persoalannya. Para santri yang berfungsi sebagai penanggap yang berkesempatan untuk menaggapi apa yang disajikan oleh penyaji yang mendapat tugas.

Kegiatan penilaian dilakukan oleh kyai atau ustadz selama kegiatan musyawarah berlangsung. Hal-hal yang menjadi perhatiannya adalah kualitas jawaban yang diberikan oleh peseta yang meliputi : kelogisan jawaban, ketepatan, dan kevalidan refrensi yang disebutkan serta bahasa yang disampaikan dapat dengan mudah dapat sifahami santri lain, serta kualitas pertanyaan atau sanggahan yang dikemukakan. Hal lain yang dinilai adalah pemahaman terhadap teks bacaan, juga kebenaran dan ketepatan peserta dalam membaca dan menyimpulkan isi teksyang menjadi persoalan atau teks yang menjadi rujukan.

Keempat, Metode Pengajian Pasaran. Metode pengajian pasaran adalah kegiatan pembelajaran para santri melalui pengkajian materi (kitab) tertentu pada seorang kyai/ustadz yang dilakukan oleh sekelompok santri dalam kegiatan yang terus menerus (marathon) 
selama tenggang waktu tertentu. Pada umumnya dilakukan pada Bulan Ramadhan selama setengah bulan, dua puluh hari, atau terkadang satu bulan penuh tergantung pada kitabnya yang dikaji. Metode ini mirip dengan metode bandongan, tetapi pada metode ini target utamanya adalah "selesai"nya kitab yang dipelajari. Pengjian Pasaran ini dahulu banyak dilakukan dipesantren-pesantren tua di Jawa, dan dilakukan oleh kyai-kyai senior dibidangnya. Titik beratnya pada pembacaan bukan pada pemahaman sebagaimana pada metode bandongan. Sekalipun dimungkinkan bagi para pemula untuk mengikuti pengajian ini, namun pada umumnya pesertanya terdiri dari mereka-mereka yang telah belajar atau membaca kitab tersebut sebelumnya. Kebanyakan pesertanya justru para ustadz atau para kyai yang datangdari tampat lain yang sengaja dating untuk itu. Dengan kata lain, pengajian ini lebih banyak untuk mengambil berkah atau ijazah dari kyai-kyai yang dianggap senior.

Dalam perspektif lebih luas, pengajian ini dapat dimaknai sebagai proses pembentukan jaringan kitab-kitab tertentu diantara pesantren-pesantren yang ada. Mereka yang mengikuti pengajian pasaran di tempat tertentu akan menjadi bagian dari jaringan pengajian pesantren itu. Dlam konteks pesantren hal ini amat penting karena akan memperkuat keabsahan pengajian dipesantren-pesantren para kyai yang telah mengikuti pengajian pasaran ini.

Sebelum memasuki bulan ramadhan, beberapa pesantren biasanya mengeluarkan jadwal, jenis kitab, dan kyai yang akan melakukan balagh pasaran di bulan itu. Berdasarkan itu, santri, ustadz atau kyai yang berminat akan merencanakan sendiri kemana ia akan menuju dan kitab apa yang ia pilih. Biasanya kitab yang akan dipilih ialah kitab yang pernah ia pelajarinya, namun membutuhkan penguatan, atau ada kalanya kitab yang sulit sekali diperoleh pengajiannya ditempat lain pada waktu-waktu biasa. Memang ada kalanya untuk pasaran seorang kyai sengaja membaca kitab yang jarang dibaca kyai lainnya. Untuk mereka yang sengaja datang untuk pasaran, pesantren biasanya menyediakan tempat khusus. 
Kegiatan pengajian itu sendiri biasanya dilakukan sepanjang hari. Waktu istirahat biasanya hanya shalat, waktu beruka puasa, dan setelah jam dua belas malam. Kitab yang telah ditentukan dibaca dan diterjemahkan oleh seoarang kyai secara cepat, sedangkan santri menyimak untuk memberikan catatan pada bagian-bagian tertentu saja atau mencatat penjelasan-penjelasan singkat yang biasanya memang diberikan.

Setelah pembacaan selesai (khatam), para santri kembali pesantrennya semula. pengajian berakhir biasanya beberapa menjelang datangnya Idul Fitri. Disini tidak dilakukan sama sekali konfirmasi ulang kepada kyai sekalipun, misalnya sebagian santri memerlukan tambahan keterangan atau penjelasan.

Pengajian pasaran ini sesungguhnya amat besar maknanya, mengingat kebanyakan yang mengikutinya ialah mereka-mereka yang memiliki pengalaman atau kemampuan tertentu, khususnya kitab yang akan dibaca atau dikaji. Salah satu cara untuk meningkatkan efektifitasnya ialah dengan meniadakan pengertian harfiah sebagai pengajian sorogan tingkat awal, hanya membacanya secara benar dan memberikan ulasan-ulasan singkat pada topik yang dianggap penting.

Kegiatan pembelajaran dengan menggunakan metode pengajian pasaran merupakan pengajian yang hampir sulit dievaluasi. Tanda keberhasilanya yang paling dapat diukur adalah apabila pengajian itu dapat diselesaikan, atau kitab dapat dibaca hingga selesai (khatam). Kebanggaan santri adalah selama dalam bulan Ramadhan itu merampungkan kegiatan pengajian pasarannya dengan beberapa buah kitab yang banyak halamannya (tabal).

Kelima, Metode Hafalan (Muhafazhah). Metode hafalan ialah kegiatan para santri dengan cara menghafal suatu teks tertentu dibawah bimbingan dan pengawasan kyai/ustadz. Para santri diberi tugas untuk menghafal bacaan-bacaan salam jangka waktu tertentu. Hafalan yang dimiliki santri ini kemudian dihafalkan dihadapan kyai/ustadz secara periodic atau incidental tergantung pada suatu petunjuk kyai/ustadz yang bersangkutan. Materi pembelajaran dengan metode hafalan 
umumnya berkenaan dengan Al-Qur'an, nazham-nazham untuk nahwu, sharaf, tajwid, ataupun untuk teks-teks nahwu sharaf dan figh.

Dalam pembelajarannya metode ini seorang santri ditugasi oleh kyai untuk menghafalkan satu bagian tertentu atau keseluruhan dari sesuatu kitab. Titik tekan metode ini santri mampu mengucapkan/menghafalkan kalimat-kalimat tertentu secara lancar tanpa teks. Pengucapan tersebut dapat dilakukan secara perorangan maupun kelompok. Metode ini dapat juga digunakan dengan metode bandongan atau sorogan. Untuk mengevaluasi kegiatan belajar dengan metode hafalan ini dilakukan dengan dua macam evaluasi yaitu: pertama, dilakukan pada setiap kali tatap muka, dan yang kedua pada waktu yang telah dirampungkan/diselesaikannya seluruh hafalan yang ditugaskan kepada santri.

Keenam, Metode Demontrasi/Praktek Ibadah. Metode ini adalah cara pembelajaran yang dilakukan dengan memperagakan (mendemontrasikan) suatu ketrampilan dalam hal pelaksanaan ibadah tertentu yang dilakukan secara perorangan maupun kelompok dibawah bimbingan dan petunjuk kyai atau ustadz, dengan beberapa kegiatan, yaitu: 1) para santri mendapatkan penjelasan/teori tentang tata cara (kaifiat) pelaksanaan ibadah yang akan dipraktekkan sampai meraka betul-betul memahaminya. 2) Para santri berdasarkan bimbingan kyai/ustadz mempersiapkan segala perlengkapan atau peralatan yang diperlukan kegiatan praktek. 3) Setelah menentukan waktu dan tempat para santri berkumpul untuk menerima penjelasan singkat berkenaan dengan urutan kegiatan yang akan dilakukan serta pembagian tugas kepada para santri berkenaan dengan pelaksanaan praktek. 4) Para santri secara bergiliran/bergantian memperagakan pelaksanaan praktek ibadah tertentu dengan dibimbing dan diarahkan oleh kyai atau ustadz sampai benar-benar sesuai kaifiat (tata cara pelaksanaan praktek ibadah sesungguhnya). 5) Setelah selesai kegiatan praktek ibadah para santri diberikan kesempatan mempertanyakan hal-halyang dipandang perlu selama berlangsung kegiatan.

\section{Masa Pembelajaran dan Syahadah (Ijazah)}


Masa pembelajaran adalah jangka waktu yang tertentu yang dihabiskan untuk menempuh pendidikan dipondok pesantren. Masa pembelajaran sangat bergantung pada model pembelajaran yang ada. Karena model pondok pesantren yang secara langsung berhubungan dengan model pembelajarannya yang bermacam-macam bentuknya, maka masa atau waktu belajar yang dimanfaatkan oleh para santri dipondok pesantren menjadi berbeda-beda pula.

Masa pembelajaran di pesantren yang menyelenggarakan pendidikan formal lebih tampak dalamsatuan waktu. Satuan waktu tersebut dapat berupa semester, catur wulan, tahun, dan keseluruhan program dalam kurun waktu tertentu, seperti enam tahun untuk MI, tiga tahun untuk MTs dan seterusnya. Satu tahun. Nama masing-msing pembelajaran yang berbeda-beda, misalnya kelas, marhalah, fashal, thabaqah, sanah, dan sebagainya.

Rata-rata pembelajaran pondok pesantren tergantung pada pimpinan yang bersangkutan, dewan Pembina atau dewan pengajarnya. Bisa mencapai tiga atau enam tahun, atau tergantung kelulusannya pada lembaga pendidikan formal yang juga diselenggarakan oleh pondok pesantren. Pengjian ini tidak dibatasi dengan batas waktu tertentu dan tanpa perjanjian khusus. Selesainya masa pelajaran adalah jika ia sudah merasa cukup atau kyai menganggap dirinya cukup memiliki pengetahuan atau ajaran agama Islam.

Pada saat santri selesai atau dianggap cukup dalam menerima pendidikan, baik itu berupa pengajian dan pendidikan ketrampilan biasanya, ia akan menerima ijazah, sebagaimana halnya yang terjadi pada sekolahan umum, madrasah atau lembaga pendidikan lainnya. Ijazah (syahadah), merupakan lembaran yang menunjukkan atau tanda bukti bahwa telah selesainya pendidikan seseorang disuatu perguruan untuk masa pembelajaran tertentu. Tidak seragam dengan kata ijasah. Ada yang menyebutnya dengan syahadah dan lainnya (Bimbaga, 2003:43-48).

\section{Penutup}


Indonesia sebagai negara berpenduduk muslim terbesar di dunia, tidak lepas dari akar sejarah pengkajian agama Islam dan bahasa Arab yang kokoh di berbagai elemen masyarakat muslim Indonesia, utamanya masyarakat berbasis pesantren tradisional yang dari masa ke masa terus berkembang dan berimprovisasi seiring dengan kemajuan jaman.

Dengan sistem pengajaran yang khas, pesantren tradisional telah mampu memproduk ulama-ulama besar di Indonesia yang lewat tangan-tangan dingin mereka Islam dan bahasa Arab akan selalu menyertai dinamika berbangsa dan bernegara dalam rentangan sejarah bangsa dari masa ke masa. Jika tradisi pengkajian agama Islam dan pelestarian kitab-kitab turats (tradisional) di pesantren-pesantren yang ada di Indonesia terus berlangsung dan selalu berkembang, maka tidak mustahil, apabila di kemudian hari nanti, Indonesia menjadi pusat pengembangan Islam dan bahasa Arab di dunia. $\square$

\section{DAFTAR PUSTAKA}

Bawani, Imam. 1993. Tradisionalisme dalam Pendidikan Islam. Surabaya: Al Ikhlas.

Bimbaga Islam Depag RI. 2003. Pondok Pesantren dan Madarsah Diniyah Pertumbuhan dan Perkembangannya. Jakarta: Depag RI.

Dhofier, Zamakhsyari. 1994. , Tradisi Pesantren. Jakarta: LP3ES.

Glasse, Cyril. 1999. Ensiklopedi Islam. Jakarta: Raja Grafindo Persada.

Maksum. 1999. Madrasah Sejarah dan Perkembangannya. Jakarta: Logos.

Poerwadarminta, WJB. 1982. Kamus Umum Bahasa Indonesia. Jakarta: Balai Pustaka.

Prasodjo, Sudjoko dkk. 1982. Profil Pesantren. Jakarta: LP3ES.

Sumajuntak, IP. 1973. Perkembangan Pendidikan di Indonesia. Jakarta: Depdiknas.

Wahid, Abdurrahman. 1974. "Pesantren Sebagai Subkultur" dalam Dawam Rahrdjo (Ed), Pesantren dan Pembaharuan. Jakarta: LP3ES. 
Wahid, Abdurrahman. 1974. Pesantren Sebagai Subkultur, dalam Pesantren dan Pembaharuan, Dawam Rahrdjo (Ed),. Jakarta: LP3ES. Yunus, Mahmud. 1979. Sejarah Pendidikan Islam di Indonesia. Jakarta: Mutiara.

Zarkashiy, Ahmad Hidayatullah. 1991. Al-Lughoh Al-'Arabiyah fii Induunisiyya Diraasatan wa Tariikhon. Lahor-Pakistan: Universitas Punjab. 